\title{
工業化學雜誌 第三五編 第四册
}

\author{
第四一○號（昭和七年四月）
}

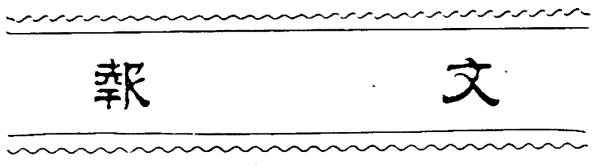

（京都帝國大學工學部工業化學科湖究室）（昭和七年一月四日受理）

\section{亞 麻 仁油酸 化に對する 光の影響 (第一報) \\ 福島 郁三・堀尾 正雄 · 三木 飭夫 \\ 緒言}

乾性油酸化に對する定量的研究特に光の影響に就いての肪究はその數多からざれども乾性油を光に嚗射せる 場合暗所に於けるより一層速かに翰燥する事筫は古くより認めらる從來の諸幵究中特に注目すべきはゲンテ氏

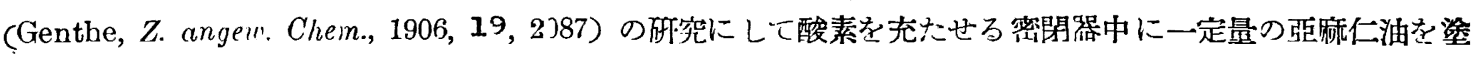
りたる一定面樍の濾紙を吊るし水銀登に暴射せる場合としからざる場合とを比較せりその結果水銀登に㩧射せ ざる場合の酸素吸收量 $22.6 \%$ なるに對し同一眭間水銀燈に暴射せる場合はその酸素吸收量 $25.8 \%$ に增加せる 事を認めたり

ゲンテ氏に前後してクロエッ氏 (Cloez, Chem. R:v，1898, 5, 2) ウォルフ氏 (Wolff, Fä:b. Ztg., 1919, 24，1119）アイブナー氏 (Eibner, Färb. Zlg., 1920，26，2397）仅田中芳雉、中村三男兩氏（本誌、昭 5, 33， $338,398,395,402)$ 等の研究あり

油の酸化郎ち乾燥に就き考ふるに從來多くの砄究發表されたるもその酸化行程を簡單且一般的に表示する事 は困難にして複雜なる機構の存在せるものの如し現今一般に認めらるる證は酸化行程に於て初期にまゔ不安定 なる過酸化物が中間體として生成しこの中間體が更に進儿て酸化生成㗐に移り乾燥の現象を示寸郎ち直ちに酸 化生成體に移るにあらずして中間嗹なる段階を經て乾燥するに至る

著者等は種々の條件のもとにて亞麻仁油に紫外光線を作用せしめその影響を考察せんとするものにして本報 に於てはその基燓的解究を報告す

$$
\text { 試料 }
$$

試料としては日本藥局法亞麻仁油を使用せりその特數を示せば次の如し

比重 $\left(d 25^{\circ}\right.$ ○) 0.9284 ；比粘度 $\left(25^{\circ} \mathrm{C}\right) 0.5071$ (オストワルド比粘度計を用ひグリセりンと比较す); 屈折率 $\left(25^{\circ} \mathrm{C}\right) 1.4770$ (アッべ氏屈折率計による)；水分 $0.1 \%$ (不綿を入れたる容惩に試料約 $10 \mathrm{~g}$ を入れ水素を 6 時間 吹迈みてその重量減少より測定せり); 酸價 1.00 ; 沃素價 180.5 (ウィス氏法 2 時間)

$$
\text { 测定方 法 }
$$

本報に於ては油の酸化行程を指示するに主として沃素價の變化を以てせり

妶に注意すべきは沃素價の減少は酸化と本行に進むと云へども精密には酸化程度を指示する唯一の因子たり 
と云ふを得ず郎ち光處理又は熱處理特に高溫に於ては油が酸化以外に重合、縮合、分解等を起しその結果沃素 價に影響を及ぼすことあればなり

沃素價測定はウィス氏法によれりその測定誤善は $0.3 \%$ 以內なり

测定裝 嗔

露光裝置は著者等が先に發表せるギアゾ化合物の光分解 (本誌、昭 6, 34, 981; Memoir of Coll. Engneer. Kyoto Imp. Univ. Vol. 6, 214) に使用せしものと咯同一裝置なり郎ち光源としては水銀弧燈を使用せり該弧 燈の輻射エネルギーを均一に保つため通風空を有する箱中に設置し且絕えず注意して電流電巸を均一に保てり 佾輻射エネルギーは銳敏なる兟電錐を以て測定せるに $10 \%$ 以內の變化にて均一なる事を確めたり露光用反應 容器は鼓形にして圓形前面 (面䅪 $10 \mathrm{~cm}^{2}$ ) に水晶板をはり $10 \mathrm{cc}$ の試料油を充たして大なる恒溫槽中に浸漬す 恒溫慒には光線導入のため水晶板をはりたる空を作りそれが直後に反應容器を固定す

試料油は露光中目的に應じて種々の瓦斯を吹込みて攢挥寸之に對しては精製せる瓦斯を內徑 $0.4 \mathrm{~mm}$ の确子 毛細管を通じて一定速度にて反應容器底部より水晶板に沿ひ上舁せしむる如く油中に泡出せしむ

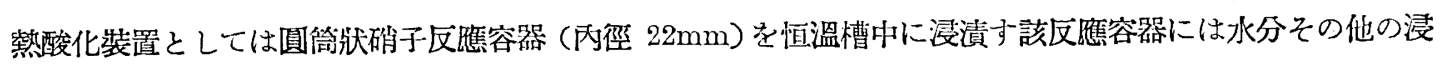
入を防ぐため硝子柽を施し之にうがてる內徑 $3 \mathrm{~mm}$ の硝子管を通じて酸素を容器內に怃り底部より油中に泡出 せしめ撥瓦斯は他の硝子管を經て外部に導く

實 驗 操 作

水銀弧燈のエネルギー均一になりたる後試料油 $10 \mathrm{cc}$ を充たせる反應容器に光線冷却器にて跷を奪ひたる光 線を入射せしめ之と同時に砣子毛細管を通じてフローメーターにて一定速度に調節しつ〉 1 時間 $3 l$ の割合に 譏料油中に酸素を吹迈九露光中はたえず水銀燈のエネルギー及酸素を一定に保つ樣注意せりかくして 3 時間或 は 6 時間露光を續けたる後露光による油の性狀戀化を測定するため油の小部分を取り直ちに殘部を熱酸化用反 應容器に入れ $55^{\circ} \mathrm{C}$ 或は $70^{\circ} \mathrm{C}$ の恒溫槽に浸漬し同牌に 1 時間 57 . の割合にて一定速度にて酸素を吹込むこの 場合もたえずフローメーターに注意し酸素流出速度を均一ならしむる樣調節せり少この加溫による熱酸化の行 程を知るため一特間每に小部分を取出して沃素價を測定せり

又別に露光用裝置を用ひ只水銀登に曝射することなくその他は全く同一條件の下にて酸素を 3 時間或は 6 時 留饮迈みたるものを熱酸化裝置にろつしてその酸化行程を前の如く測定し又前操作を全然行はざる原試料油を

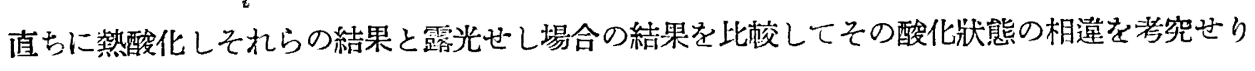

露光による性質變化

I. 露光前後に於ける特數の變化は次の如しこの際露光溫度は䇆料油のうける熱酸化を成可く緩慢ならしむ るため $5^{\circ} \mathrm{C}$ の低溫を選びたり

第一表に見る如く比重及比粘度は幾分增加を示し屈折率、酸價はその檑加極めて僅少にして㱠んと變りなし 夭素價は幾分減少するもその變化は僅少なりかくの吝く露光に依り上記の特數の上に現はれる變化は概して顯 著ならず（後表に見る如く6 時鼬暗所にて酸素を通じたるものは沃素價減少せず）

II. 露光に依る特數の變化は以上の如く僅小なれどもこ〉に注目すべきは次に行ふ熱酸化による酸化行程の 著しき相違にして預め露光せし亞麻仁油は露光せざりしものに比してその酸化一層速かなるを認む以下順次そ の辋䮰結果を示さんとす 
第二表及第一圖にては前操作を行はざるもの（A）前操作として前述の方法にて暗所にて 3 時間酸素を吹迈 みたるもの (B) 前述の裝置にて 3 時間露光せしもの (C) の熱酸化行程を示す

一時間每の沃度價減少數を以て假りに酸化速度を示寸事は上下諸表に就いても同樣なり

\section{第 一 表 \\ 露光時閒 3 時間 露光溫度 $5^{\circ} \mathrm{C}$}

露光前露光後

沃素嘼

180.5

178.9

露光時間 6 時間 隔光溫度 $5^{\circ} \mathrm{C}$

露光前露光後

比 重 $\left(d_{25^{\circ} \mathrm{C}}\right) \quad 0.9284$

比粘度 $\left(25^{\circ}\right) \quad 0.5071$

屈折率 $\left(25^{\circ}\right) \quad 1.4770$

較價 1.00

沃素侕 180.5

0.9353

0.6057

1.4775

1.04

176.8

第二表及第一圖を見るに A は 3 時間迄は沃素價 を減ぜすして同一值を保ちその後徐々に酸化進み酸 化速度は次第に增大して 9 時間 乃至 10 時間にて最 大に達す B は殆んど A に一致すこの結果より見る 時は油に豫め酸素を導入すとも光線を送らざれば該
第二表（露光せるものと、せざる油の 加熱に對する性狀の比較)

露光溫度 $5^{\circ} \mathrm{C}$ 加溫溫度 $55^{\circ} \mathrm{C}$

$\overbrace{\mathrm{A}}^{\mathrm{B}} \mathrm{C}$

前操作を行

加はざるもの酸素を吹込

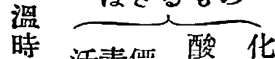

間

間

1

2

3

3

4

5

6

7

8

9
10

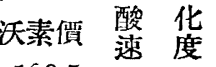

$1 \varepsilon 0.5$

-

沃素僄

180.5

180.5

180.5

180.0

179.1

177.4

175.1

酸素導入の8

とK光時間露

光せしもの

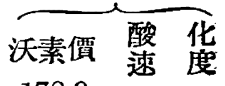

178.9

178.9

0

$180.7 \quad 0$

177.7

1.2

$181.0 \quad 0$

$179.5 \quad 1.5$

177.4

2.1

0.9

173.0

3.5

168.8

4.2

$164.6 \quad 4.2$

$160.2 \quad 4.4$

175.2

172.4
油はもとのものに比して殆んと變化を蒙り をらざる事を知る之に反して C は最初の一 時間より沃素價減少し始め A. B より大な る酸化速度にて次第に減少す郎ち预め露光 せしものは露光せざるものに比しその酸化 速度の最大值が一詹速かに現るるを見る

次に前操作を行はざるるの (A)、暗中 6 時間酸素を欦込みたるもの (B)、6 時間露 光せしもの (C) を䇛酸化を行ひたる結果 は筫三表及第二圖の如し

本圖に於て B は最䘞 2 時間程はその沃 素價を減少せずして A に沿ひて進むる 2 時間以外は A よりや」大なる速度を以て 酸化小次に露光せる油 Cに就いて見るに最 初より沃素價減少著しく $\mathrm{A}, \mathrm{B}$ より遥かに 大なる酸化速度にて酸化進行し短時間にて 最大值に達しその後減少の倾向を示寸 $\mathrm{C} か ゙$ 最大値に達する時間は A の 9 時間乃至 10 時閒及第一圖 $\mathrm{C}$ の約 7 時間なるに比し遥

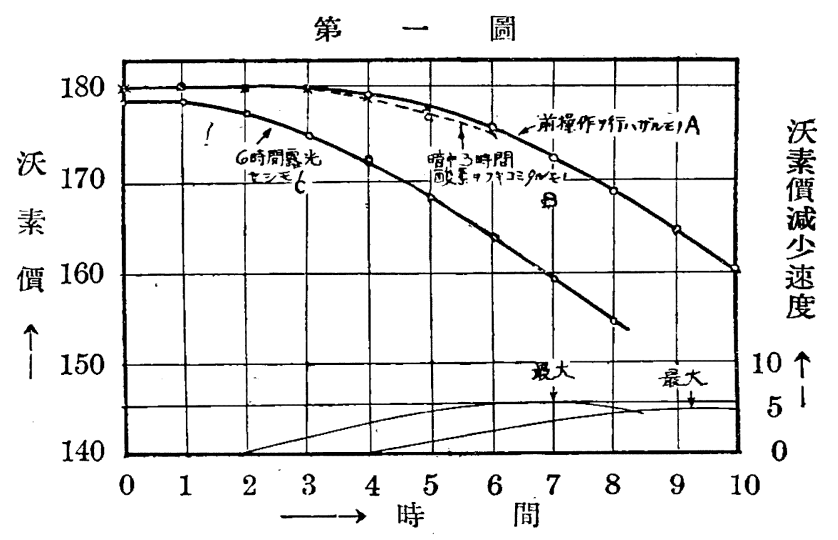

細線にて示す曲線は酸化速度を表はす

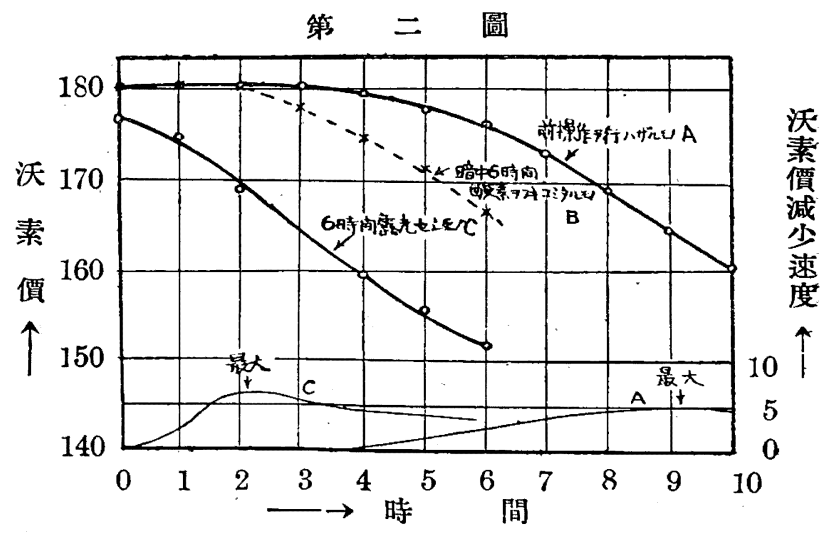

細線にて示す曲線は酸化速度を表はすす 
に速かにして露光後 2 時間乃至 3 時間にて既に最大值に達す

次に露光温度 $20^{\circ} \mathrm{C}$, 加溫溫度 $70^{\circ} \mathrm{C}$ となしその他の條件及装置は前と全く同樣にして實驗せりこの際露光後 の沃素價減少は $5^{\circ} \mathrm{C}$ の場合に比しや〉大なる.もその差極めて小なり又䓡酸化の場合は $55^{\circ} \mathrm{C}$ の洔に比し酸化速 度增大せり

本實驗に於て露光せざる原試料油 (I)、3 時間露光せしもの (II) (露光により沃素價は 178.8 に減少せり)、 6 時間露光せしもの (III) (露光により沃素價は 174.0 に減少せり) $70^{\circ} \mathrm{C}$ にて熱酸化を行ひたる結果は第 四表及第三圖の如し

第三表 露光温度 $5^{\circ} \mathrm{C}$ 加潈潈度 $55^{\circ} \mathrm{C}$

（露光油及無露光油の加熱に對する性狀の比較）

A

$B$

$\mathrm{C}$

前操作を行

加はざるの 酸素を吹込

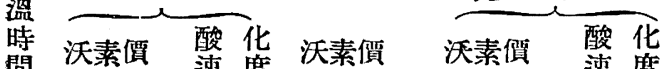

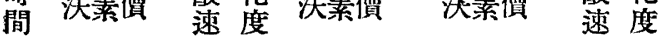

$\begin{array}{llllll}0 & 180.5 & - & 180.5 & 176.8 & -\end{array}$

$\begin{array}{llllll}1 & 180.6 & 0 & 180.7 & 174.8 & 2.0\end{array}$

$\begin{array}{llllll}2 & 180.7 & 0 & 180.1 & 168.7 & 6.0\end{array}$

$\left.\begin{array}{ccccc}3 & 181.0 & 0 & 177.4 & - \\ 4 & 179.5 & 1.5 & 174.6 & 159.6\end{array}\right\}$ 平均 4.5

$\begin{array}{lllllll}5 & 177.4 & 2.1 & 171.5 & 155.9 & 3.7\end{array}$

$\begin{array}{llllll}6 & 176.5 & 0.9 & 166.6 & 152.0 & 4.9\end{array}$

第 三 圖

細線にて示す曲線は酸化速度を表はす

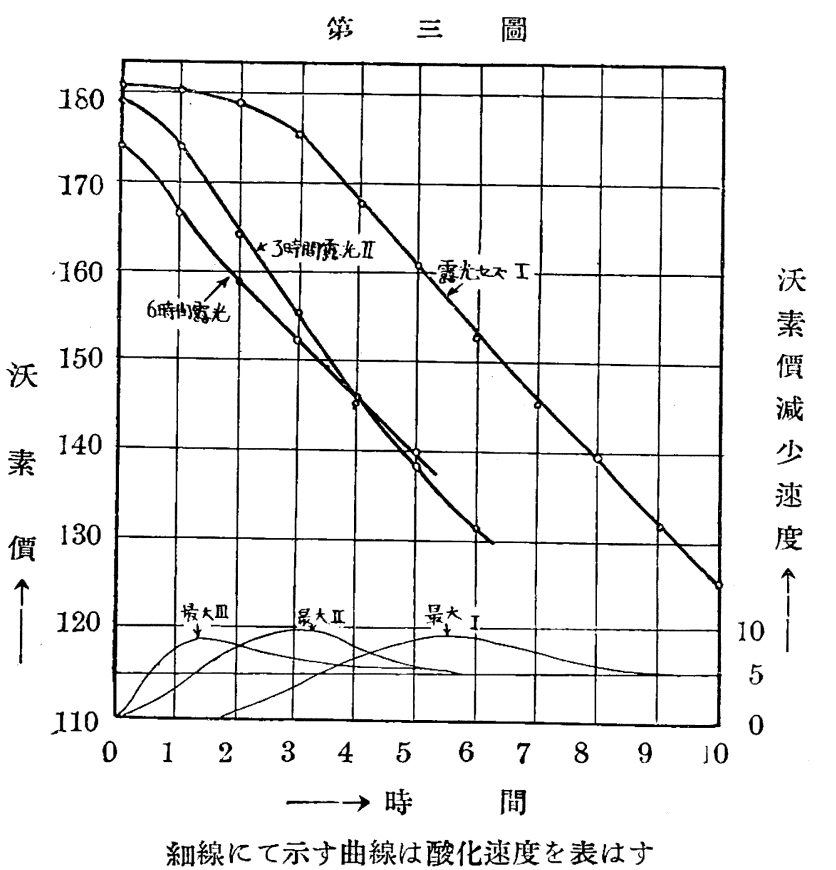

第 四表

露光溫度 $20^{\circ} \mathrm{C}$ 加溫淰度 $70^{\circ} \mathrm{C}$
I

路光せざ

उ \& 0

沃盗

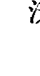

$$
180
$$$$
1
$$

2

3

4

6
7

10

第三洄に見る如くIは最初沃素偩減少極め て徐々なれども次笨にその酸化速度は加速度 的に墰大し約 6 洔間にて 最大值を取り其の後 次第に減少寸IIに於ては酸化速度の最大值 は既に 3 洔間後に表はれ III はI,IIに比し 更に速く 1 時䦧乃至 2 時間にして 最大值を示 す份酸化速度の最大値を比校するに I, II, III 共にその相違大ならず

以上實踰結果よりして 露光せるものは露光 せざるものに比し加熱により酸化速度の墦加 在認导

緒言に於て述べたる如く乾性油の酸化行程 はその機桪複椊にして本實驗に關しても更に 具蹬的の結論を得る筑には倘䔈騟的に確むべ き點むりと云へども以上の嘪驗結果よりして

次の吝く考察寸即露光により原料試油は此重、比粘度、屈折率、酸價、沃素價に於て著し.き影響を蒙り居らざ れども容易に酸化されて 酸化生成韙に變じ易き中間韙或は酸化促淮的に作用する接觸的化合物生成する如く 
考へらるしかもその生成量は露光時間長き程大なり酸化速度は最初甚だ小なるも加速度的に埇大し逐に最大值 に達しそれより次第に減少の傾向を示す份酸化速度につき注目寸べきは露光せるものは露光せざるものに比し 酸化速度の最大がより速く現はるる事䆬にしてこの際長時間露光せしものは短時間露光せるものに比し侗速か に該最大值出現す

附 記

上記考察せる如く乾性油の酸化行程は中間體なる段階を經て生成體に達するものと考へ更に又原試料油及中 間觧の酸化反應は共に一次反應なりと假定するときは次の方程式を得

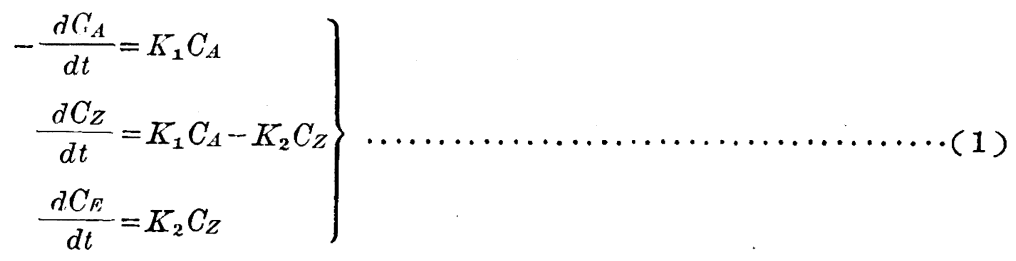

茲に $C_{A}, C_{Z}$ 及 $C_{E}$ は夫々出發化合物、中間體及終局化合物の濃度を示す、 $K_{1}, K_{2}$ は速度恒數なりこの 方程式を條件的に積分寸れば次式を得

$$
\frac{d C_{\mathrm{E}}}{d t}=\frac{K_{1} K_{2} C_{\mathrm{o}}}{K_{1}-K_{2}}\left(e^{-K_{2} t}-{ }^{-K_{1} t}\right)
$$

$C_{\mathrm{o}}$ は出發化合物の最初の濃度なり次に

$$
\frac{d\left(\frac{d C_{E}}{d t}\right)}{d t}=0
$$

と置く時は次式を得

$$
t=\frac{1}{K_{1}-K_{2}} \ln \frac{K_{1}}{K_{2}}
$$

之郎ち終局化合物の生成速度は常に速續的に增大寸るものにあらずして方程式 (3)に示さるる時間に於て最 大値に達しそれより泍次減少する事を示す露光せる油に於ても方程式 (1)に於ける如き關係は同じく成立する 筈なりもし光により生成する中間體か爇反應に於けるそれと同一物なりと假定せば露光せるものに於てはその 酸化速度の最大値がより速く出現する事は之等方程式より容易に說明し得

以上の事は實驗結果と定性的によく一致する所なるも $K_{1}, K_{2}$ 其他の值を決定する 事困難なるため值接前 記方程式に數値を代入し實驗結果と比較對照して定量的に考察する事困難なり

總括

（1）亞麻仁油酸化に對する光の影響につき基礎的研究を記述せり

（2）亞麻仁油を低溫にて一定量の酸素を吹迈みつょ一定光量の水銀燈光線に 曝射したる後比較的高溫にて 一定の酸素を吹込みつ〉加溫酸化しその酸化行程を沃素價の變化を以て湘定し酸化狀態を研究せり

（3） $5^{\circ} \mathrm{C}$ にて 6 洔間露光せし油は原試料に比し比重、比粘度、屈折等、酸價、沃素價に於て著しき相違を 示さず

（4）然れども露光せし油は加熱に際し露光せざる油に比しより速かに酸化す

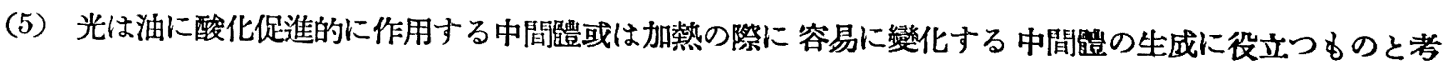


察す

（6）沃素價減少速度は酸化行程の最初に於ては甚だ小なれども次第に增大して逐に最大値に達しその後漸 次減少すこの際最大值は長時間露光せる油ほど速く現はる

\section{（退信省需氣試驗所第五部）（昭和七年一月二一日受理）

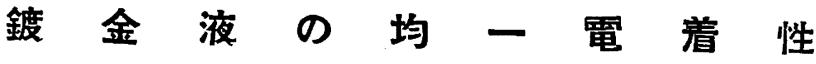 \\ 金子淸 次}

ヘーリング及びブラム兩氏 (M. E. Haring and W. Blum, Trans. Am. Electrochem. Soc., 1923, 44, 313) は陽叒よりの距離を暗にする甲及乙なる 2 枚の陰極上に於ける金屬析出量を測定し均一電着性を次の如く定義 Lた

$$
T=\frac{K-M}{K} \times 100
$$

但し $K=$ 甲と陽極との間の距離と乙と陽極閒の距唯との比

$M=乙 K$ 析出せる金屬量と甲に析出せる金屬量との此

鍍金液の均一電着性は勿論上式に㑈つて明嘹に表すことは出來るけれども與へられたる電流密度に就いては 均一電着性を表はすことが出來ぬといふ不便がある

そこで著者は均一電着性の性質を明瞭にするため次に示せる $A$ なる量を定義し之を本誌上（昭 6,34 , 353）に發表した

$$
A=-\frac{1}{Q} \frac{\partial Q}{\partial l}=\frac{1+\frac{i}{\varepsilon} \frac{d \varepsilon}{d i}}{l+\frac{1}{\rho} \frac{d v}{d i}}
$$

但し $Q=$ 單位時間內К析出さる金屬の量

$$
\begin{aligned}
& \varepsilon=\text { 電流能率 } \\
& \rho=\text { 既金液の比抵抗 } \\
& v=\text { 陰極面火於ける電源降下 }
\end{aligned}
$$$$
i=\text { 電流密度 }
$$

作しながら上式の $A$ の值は鍍金液の均一電着性が大となる程小となる樣な量であるから之を以て均一電着 性を示すのは甚だ不便であるそこでブラム氏の所論を參考として $T$ を次の式で定義することとした

$$
T=\frac{A^{\prime}-A}{A^{\prime}} \times 100
$$

但し $A^{\prime}$ は $\varepsilon=1$ 及び $d v / d i=0$ なるときの $A$ の值を示し $1 / l$ に等しい

上式に於ては $T$ が $100 \%$ の場合には $A=0$ なるを要し郎ち $d Q / d l=0$ となり金屬析出量は距離に無關 係となるから甚だ合理的である（2）を（3）に代入すれば $T$ の值は次の如く表される

$$
T=\frac{\frac{1}{\rho l} \frac{d v}{d i}-\frac{i}{\varepsilon} \frac{d \varepsilon}{d i}}{-1+\frac{1}{\rho l} \frac{d v}{d i}} \times 100
$$

$\varepsilon=1$ なるときには

$$
T=\frac{1}{1+\rho l \frac{d i}{d v}} \times 100
$$

